Gender

and

Language
G\&L (PRINT) ISSN: 1747-6321

G\&L (ONLINE) ISSN: 1747-633X

Editorial

\title{
Hope in a Time of Crisis
}

\section{Mie Hiramoto, Rodrigo Borba and Kira Hall}

A year has passed since we took over the editorship of Gender and Language. In our first editorial, we reflected on the ways that conservative forces in diverse national contexts have manipulated the feminist concept of gender, reframing feminist, queer, transgender and nonbinary demands for social and judicial reform as threats to nation and family (Borba, Hall and Hiramoto 2020). We noted with a pinch of hope that these dynamics do not go unchallenged; marginalised groups have taken to the streets to protest the re-entrenchment of masculinist discourses. Their rage against disenfranchisement transmogrified into a form of embodied agency that gained momentum as groups around the world expressed solidarity through public performances of collective action.

At the time we wrote our introductory editorial, we had no idea that 2020 would become one of the most trying years in recent history. Shortly after the issue was published, we watched from our respective vantage points as the virus turned our streets into vectors of infection - first in Singapore, then in the United States and then in Brazil. When the US public first awoke to the severity of the threat in mid-March, the American popular singer Madonna drew international criticism for posting a video of herself in a bath of rose petals reflecting on COVID-19 as 'the great equalizer': 'It doesn't care about how rich you are, how famous you are, how funny you are, how smart you are, where you live, how old you are, what amazing stories you can tell' (Owoseje 2020). Even at this early stage in the pandemic, when nearly 15,000 people had died, much of the world had already come to know that COVID-19 does indeed discriminate. In fact, the virus 'cares' deeply about many of the categories mentioned by Madonna, precisely attacking inequalities of wealth, fame, education, residence and 
age. Even the very order to self-isolate at home is class-based, privileging white-collar workers who are able to transition more easily to online environments (such as many of us in higher education) while 'essential workers' risk their lives in crowded public venues and assembly lines (such as staff at our own universities). While early reports on the gendered mortality rate in the United States suggested that more men than women were dying from COVID-19, later studies attributed this differential to women's unequal access to healthcare; that is, women often die of the virus without being properly diagnosed (Akter 2020). As the pandemic unfolded, we soon realised that communities long marginalised by systemic poverty and racism would come to bear the weight of COVID-19 fatalities. This weight is especially heavy for the members of these communities who are queer, transgender or nonbinary.

Perhaps most significantly for the study of gender and sexuality, shelterin-place orders, although necessary for slowing the pandemic's relentless rise, created the context for 'significant increases in gender-based violence in nearly all countries' (UNAIDS 2020). As researchers in our field know all too well, the home can be an especially dangerous place for women as well as queer, transgender and nonbinary people of all genders - populations that already experience inequity in accessing health services. Victims of intimate partner violence and child abuse found themselves trapped with their abusers, leading to dramatic spikes in reports of domestic violence worldwide (Bradbury-Jones and Isham 2020; Graham-Harrison et al. 2020). From within our own academic networks, we each heard stories of queer and trans students locked in with families who abhor their differences. In some cases, these living arrangements were not sustainable, forcing LGBTQIA+ individuals out of their homes at the time they most needed family support. It is not coincidental that one-fifth of the transgender people murdered worldwide in 2020 were killed in their homes (Wareham 2020), constituting the deadliest year on record for many countries, particularly those with high infection rates like the United States. Lockdown measures also had severe economic effects on gender-variant groups in many areas of the world. For example, third gender hijras across South Asia, who sustain their communities by collecting donations on the streets and performing birth celebrations in private homes, moved quickly into poverty (Baumgart and Farooqi 2020; Goel 2020; Sifat 2020). In South America, restrictive measures based on binary understandings of gender, such as the Peruvian and Panamanian decisions to designate different days for men and women to access essential services, led to direct violence perpetrated against transgender communities (Perez-Brumer and SilvaSantisteban 2020). Feminist anthropologist Sonia Corrêa (2020) characterises these sex/gender segregation measures as a form of symbolic violence 
that 'reiterate the biological determinism of sexual dimorphism'. In sum, although the pandemic concerns everyone, it does not affect the population equally.

Forty years ago, the AIDS crisis taught us that a sanitary emergency is as much a discursive construction as it is a biological fact. Representations of the illness and those affected by it influence the way people become morally accountable for its spread. Language has similarly played a critical role in the way the COVID-19 pandemic is understood and dealt with. The interconnection between language, gender and sexuality is painfully encapsulated by President Jair Bolsonaro's recent description of Brazil as a 'country of faggots' ('pais de maricas') whose citizens are afraid to venture into the streets because of a little virus (Gomes 2020). With language such as this, the act of not wearing a mask in public is transformed into an index of masculine imperviousness; falling ill becomes a sign of fragility. As Bolsonaro put it a day after testing positive for the virus last July, 'the mask is a thing for fairies' ('máscara é coisa de viado') (Moreira 2020). This COVID-related gender-based call to arms may be seen through the lens of what linguistic anthropologist Janet McIntosh (2020) dubs semiotic callousing, a process materialising here in the way that facing COVID without a mask, and then surviving it, is seen as a masculine hardening and strengthening of the nation. During the pandemic, political leaders have strategically represented people who do their part in fighting the disease as weak, cowardly and thus not worth saving. As with the pandemic more generally, people of colour have been hit the hardest by this gender-based rhetoric. In places where gender was turned into an enemy, the pandemic has helped embolden racist, misogynistic and homophobic rhetoric and policies.

As we noted in our first editorial, forms of feminist refusal afforded by new communication technologies may be catalysts for change, particularly in an era when oppressive discourses are shamelessly legitimated by world leaders. Performance scholar Diana Taylor (2020:47) has argued that a feminist-trans-queer politics of refusal 'means becoming a "who" to one another in spaces that withhold recognition, and forging spaces of appearance out of spaces of disappearance.' Within the spaces of disappearance that came from the gendering and racialising of COVID-19, BIPOC, feminist, queer and trans people forged mechanisms of enacting refusal, responding to the masculinist 'authority's hail' with 'a war cry in the face of nullification' (Taylor 2020:46). The strong engagement of people of colour in the US presidential election took the first Black and South Asian woman to the White House as Vice President, shattering a glass ceiling that has until now kept women out of higher office in US national politics. In the words of sociolinguist Denise Troutman (personal communication), 
Many BIPOC communities, particularly, put in extra sweat, tears, and labor in order to re-establish some basic human principles. Honoring the hardfought battles of the many-thousand-gone was part of the modus operandi. Their labor was not in vain. We had to step up!

Since we launched our editorship at the beginning of the year with a commentary on refusal (which we view as a form of stepping up), we want to reflect back on 2020 by discussing what we see as its affective infrastructure: namely, hope.

Since 2017, the \#MeToo movement has inspired people across the world to advocate against sexual violence more intensely than ever before. The movement has not put an end to sexual violence; indeed, as mentioned above, the pandemic has in many cases accelerated violence against women and vulnerable individuals. But the forms of refusal enacted by these populations and their allies worldwide give us hope - hope that we can find ways as academics to speak up against this injustice, that we can create the change locally that we want to see globally, that we can walk towards a better future by remaining resilient and unbroken. Even in the pandemic's most sinister moments, we saw the strengthening of the Black Lives Matter movement, tragically sparked by the brutal killing of George Floyd on the streets of Minneapolis. This too is a movement of refusal, with people of all colours, classes, genders, ages and nationalities joining together to refuse centuries of systemic racism. Resistance movements like \#MeToo and Black Lives Matter have put a much-needed spotlight on misogynist and racist violence, drawing the world's attention to forms of injustice festering in the shadows for far too long. Yet these movements for a socially just world are also centrally organised around hope, the brick and mortar of collective action.

In this regard, we want to share a small but significant story that recently took place at the National University of Singapore (NUS), where Mie currently works as Associate Professor in the Department of English Language \& Literature. Known for its patriarchal and culturally conservative values, the Singaporean state explicitly employs strategies to maintain Asian traditions while also embracing rapidly growing global trends (Pak and Hiramoto 2020; Starr and Kapoor 2020). Although the state's meritocracy scheme places strong importance on education, campus-based incidents of sexual harassment and violence - as in many areas of the world - have remained protected in a 'space of disappearance', to borrow again from Taylor (2020). However, the \#MeToo movement has steadily made its way into Singaporean universities, offering students powerful examples of what feminist refusal can look like. In 2018, a brave female student attending NUS filed a police report against a male student who secretly filmed her taking a shower at her residential hall. The university gave the perpetrator 
a 12-month conditional warning and a one-semester suspension (Teng 2019). Deeming this treatment too lenient, the female student submitted appeals to the administration for heavier punishment while posting a series of stories on Instagram to give her plight visibility (Lam 2019). Once her stories went viral, public outcry forced the education minister to review sentencing policies for sexual misconduct cases. Significantly, the NUS president delivered a public apology for mishandling the case. When a similar case came to light in 2019, this time involving seven victims, the university announced a heavier punishment that included jail time, a monetary fine and a 3-semester suspension (Lam 2020a).

The 2018 case became a landmark event not only at NUS but also at other institutions across the country. Although incidents of sexual misconduct on Singapore's campuses continued to rise after this event, women seemed more willing to report abuse now that they sensed the support of the administration. Nevertheless, their perpetrators were rarely brought to justice, continuing a trend found in universities worldwide, as the 2015 documentary The Hunting Ground (Dick 2015) powerfully exposed for institutions of higher education in the United States. A year after the shower incident described above, an NUS student was reported to the police for sexually assaulting a woman off-campus. However, the judge who later ruled on the case, noting that the student's academic records indicated 'potential to excel in life', limited the sentence to probation (Sun 2019). Later in the same year, an NUS dentistry student climbed into his ex-girlfriend's house and strangled her for breaking up with him, partially blinding her in the process. The woman's family reported the incident to the police, but a judge later sentenced the student to only 12 days of detention and 80 hours of community service (Lam 2020b). Even for this atrocious crime, the student was not expelled from the university, leading the People's Action Party Women's Wing, in a 'rare move', to release a statement questioning the appropriateness of the sentence (Lau 2020).

We report on these unfortunate events because they allow us a glimpse into the ways that hope may concretely forestall oppression. One of the most recent incidents at NUS involving sexual misconduct is a case in point: this time, collective action led to change in university policy. In August 2020, during the heart of the pandemic, two students accused a male faculty member associated with their residential college of inappropriate sexual behaviour. Upon receiving these complaints, the college began its investigation and ultimately dismissed the faculty member two months later. However, the investigation process was kept internal and a police report was never filed. Although a tight-knit community, the residential college did not take action to check whether there were other victims who may also need protection. A growing movement of students, faculty and 
alumni joined together to condemn the university for being too closed and to demand transparency and accountability. In the end, NUS admitted its mishandling of such cases and changed its investigation process to require the filing of a police report (Ang 2020; Choo 2020). Because of incidents like these, one of the first agenda items of NUS's newly launched Gender and Sexuality Research cluster is to study campus sexual misconduct, exercising anthropologist Hirokazu Miyazaki's (2004:5) observation that hope entails 'a radical reorientation of knowledge'. In sum, the progress seen at NUS over the last several years exemplifies the ways that hope, as an affective agency fuelling forms of refusal, carries the potential to change established gender orders. Hope is not an elusive, immaterial feeling; it is tangible in the ways people harness the strength to act (in this sense, see Silva and Lee 2020). To draw on the words of sociologist Manuel Castells (2015:14), 'since a distinctive feature of the human mind is the ability to imagine the future, hope is a fundamental ingredient in supporting goal-seeking action'. In other words, we act because we hope to bring change to our reality (see also Borba 2019).

This issue of Gender and Language is geared to rethinking gendered, sexual and racial orders of oppression by highlighting the semiotic actions taken by speakers to secure more hopeful futures. Taken together, the papers indicate that our field's attention to the materiality of semiotic resources provides a privileged analytical perspective for unpacking the 'discursive and metadiscursive range of hope' (Capranzano 2003:4) and enriching our field with hope's forward-looking indexical potential. As the affective infrastructure of refusal, hope materialises in semiotic acts that temporarily reorient unequal power relations by shifting the way they are structured: 'semiotic acts of hope involve the situated emergence of signs that disrupt established oppressive orders by creating a sense of possibility, of a reconfigured present and of a future that has no place as of yet but can acquire one' (Borba 2019:174). In other words, hope is the warp and weft of agency, so much so that it is difficult to tell where one ends and the other begins.

This entanglement is seen in Adrienne Ronee Washington's opening study of the activist strategies of Black women in US politics. Her article provides a cogent example of how the linguistic refusal of white supremacist patriarchy is affectively harnessed by women's capacity for semiotic action. Focusing on cases of signifying and semantic reclamation - namely, Maxine Waters' assertion 'Reclaiming my time', Therese Okoumou's rehashing of Michelle Obama's 'We go high' and Samirah Raheem's resignification of 'slut' - Washington draws upon intersectional feminist perspectives to show how African American Women's Language offers Black women semantic and rhetorical affordances to subvert gendered and 
racialised power relations, thereby carving out a space of appearance where their voices can be heard. From a different vantage point, Hadar Netz and Ron Kuzar take issue with the claim that the literary reversal of gender roles and stereotypes in children's non-sexist literature is unfeasible. Rather, they illustrate how feminist perspectives may make their way into the narratives of Hebrew picture books. In their refusal to abide by the scientific lore of the field, Netz and Kuzar demonstrate how female protagonists in their corpus navigate the line between stereotypical and antistereotypical performances of gender. They find a subset of picture books that do indeed successfully advance what they call 'anti-sexist' narratives by featuring female protagonists who challenge patriarchal orders. In the issue's third article, Eliane Regina Crestani Tortola and Larissa Michelle Lara draw on a form of Foucauldian discourse analysis to probe a corpus of lyrics by Brazilian composer Chiquinha Gonzaga (1847-1935). Their analysis tracks the regimentation of women's bodies in the linguistic use of 'devices' based on reproductive sexuality and racial whitening which are still pervasive today. Despite the recalcitrance of these devices of objectification, Tortola and Lara conclude, with a pinch of hope, that refusing pre-established ideas and displacing hegemonic perceptions of the feminine is possible since power and resistance walk hand in hand.

It is in this spirit of hopeful refusal to well-established orders that we offer our final journal issue of 2020. To this end, we have introduced two initiatives that we are immensely proud of as editors. First, upholding the field's concern for linguistic and social inclusivity, we are now including authors' gender pronouns on the title page of each article, together with authors' names and affiliations. To our knowledge, Gender and Language is the first journal to include gender pronouns in this way. Over the last decade, queer, trans and nonbinary people have increasingly contested the binary grammatical systems that organise many languages and claimed their right to self-determination by repurposing pronouns as badges of gender variance. As indicated by the Lesbian, Gay, Bisexual, Transgender Resource Center at the University of Wisconsin, 'referring to people by the pronouns they determine for themselves is basic to human dignity. Being referred to by the wrong pronouns particularly affects transgender and gender nonconforming people. Together, we can transform society by celebrating people's multiple intersecting identities' (LGBTRC 2019; see also Zimman 2019). It is our hope that the inclusion of gender pronouns as an editorial policy will make Gender and Language more trans-inclusive by refusing cisnormative practices of identification and language use. With this initiative, we want to highlight that big acts of hope often come in small linguistic packages. 
The growing inclusiveness and self-criticism of the field is also foreshadowed by the second editorial initiative we introduce in this issue: the new Language, Gender and Sexuality Year In Review series, to be published annually. The final article in the issue, authored by Jeremy Calder, offers a précis of the field's state of the art in 2019. In a critical reading of research published during the last year, Calder paints a thorough portrait of the field and highlights its most salient trends. They argue that the study of language, gender and sexuality has increasingly crossed geopolitical, racial, linguistic and gender axes of knowledge production, becoming ever more attuned to intersectional nexus points along which language, gender and sexuality are entangled and through which power flows multidirectionally. According to Calder, this has allowed the field to enrich its interrogation not only of the ways speakers produce norms that constrain how men, women, queer, trans and nonbinary people are viewed, but also of the ways the field itself has produced its own normativities by delimiting the methods, topics and subjectivities that 'count' within the prototypical study of language, gender and sexuality. The interrogation of these two directions of normativity in 2019 has led to more fine-grained accounts of the relationship between language, identity and speaker agency. Importantly, Calder's review offers multiple examples of how forms of gendered, racial, classed and geopolitical inequalities are challenged by localised forms of refusal, both embodied and linguistic.

We began this editorial on a sombre note, reflecting on the devastation wrought by the pandemic for persons already marginalised by systems of gender and sexuality. The virus has also taken its toll on academic publishing. Even though we have worked to maintain the journal's strong reputation for showcasing innovative research on language, gender and sexuality, subscription rates to journals like ours have plummeted. Moreover, submission rates from female authors in particular have declined due to increased caretaking responsibilities under COVID-19 (Flaherty 2020). However, in spite of the financial, physical and emotional burdens we have all had to tackle, Gender and Language thrives due to the resilience and strength of our community. We would like to take this opportunity to express our appreciation to Janet Joyce and Ailsa Parkin from Equinox and to our copyeditor Rivka Israel for their commitment to the journal. We are also grateful to the International Gender and Language Association (IGALA) - our co-Presidents Holly Cashman and Claire Maree, the Executive Board and the entire IGALA membership - for building a sorority (of sorts) on which we can rely. The journal's success also depends on the huge talent found in our Editorial and Advisory Boards and on the excellent work of PhD students like Ayden Parish (our line editor assistant) and Olivia Hirschey 
Marrese (our social media manager). We are also incredibly fortunate to have Federica Formato as our book review editor.

The sense of community upholding the journal and giving us strength reflects the feminist impetus that originated the field of language, gender and sexuality. In our discussion of gender inequities framing the COVID19 pandemic and NUS incidents of sexual misconduct, we provided strong examples of the physical and discursive violence frequently faced by members of marginalised communities. Yet we also provided examples of collective actors who garnered the strength to speak out and refuse these forms of injustice. As Taylor (2020) explains, the very act of appearing - of making oneself present regardless of systemic forms of erasure - is an act of refusal toward oppressive regimes. Hope, as the affective infrastructure of refusal, creates opportunities for these spaces of appearance to emerge, inspiring inventive forms of collective agency.

\section{References}

Akter, Sonia (2020) The gender gap in COVID-19 mortality in the United States. Feminist Economics. https://doi.org/10.1080/13545701.2020.1829673

Ang, Hwee Min (2020) Student group calls on NUS to show 'transparency and accountability' in handling case of professor sacked for inappropriate behavior. Channel News Asia, 19 October. https://www.channelnewsasia.com/news/ singapore/jeremy-fernando-nus-tembusu-safe-nus-13315172

Baumgart, Phillip and Farooqi, Shariq (2020) India's hijras find themselves further marginalized amid the pandemic. New Atlanticist, 17 July.

https://www.atlanticcouncil.org/blogs/new-atlanticist/ indias-hijras-find-themselves-further-marginalized-amid-the-pandemic/

Borba, Rodrigo (2019) Injurious signs: the geopolitics of hate and hope in the linguistic landscape of a political crisis. In Amiena Peck, Christopher Stroud and Quentin Williams (eds) Making Sense of People and Place in Linguistic Landscapes 161-181. London: Bloomsbury.

Borba, Rodrigo, Hall, Kira and Hiramoto, Mie (2020) Feminist refusal meets enmity. Gender and Language 14(1): 1-7. https://doi.org/10.1558/genl.40883

Bradbury-Jones, Caroline and Isham, Louise (2020) The pandemic paradox: the consequence of COVID-19 on domestic violence. Journal of Clinical Nursing 29(13-14): 2047-2049. https://doi.org/10.1111/jocn.15296

Capranzano, Vincent (2003) Reflections on hope as a category for social and psychological analysis. Cultural Anthropology 18(1): 3-31.

https://doi.org/10.1525/can.2003.18.1.3

Castells, Manuel (2015) Networks of Outrage and Hope: Social Movement in the Internet Age. Cambridge: Polity.

Choo, Daryl (2020) NUS files police report against sacked Tembusu College lecturer accused of sexual misconduct. TODAY, 21 October. https://www. todayonline.com/singapore/nus-files-police-report-against-sacked-tembusucollege-lecturer-accused-sexual-misconduct

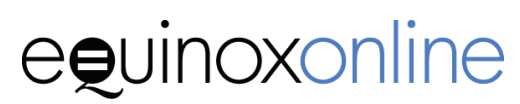


Corrêa, Sonia (2020) Back to where we always have been: sex/gender segregation to contain Covid-19. Engenderings, The London School of Economics and Political Science, 9 April. https://blogs.lse.ac.uk/gender/2020/04/09/back-to-where-wealways-have-been-sex-gender-segregation-to-contain-covid-19/

Dick, Kirby (dir) (2015) The Hunting Ground. New York: The Weinstein Company.

Flaherty, Colleen (2020) Something's got to give. Inside Higher Ed, 20 August. https://www.insidehighered.com/news/2020/08/20/ womens-journal-submission-rates-continue-fall

Goel, Ina (2020) Impact of Covid-19 on hijras, a third-gender community in India. Society for Cultural Anthropology Editor's Forum, 4 May. https://culanth.org/ fieldsights/impact-of-covid-19-on-hijras-a-third-gender-community-in-india

Gomes, Pedro Henrique (2020) O Brasil tem que deixar de ser um país de de maricas e enfrentar a pandemia de peito aberto [Brazil has to stop being a country of faggots and face the pandemic upfront]. O Globo, 11 November. https:// g1.globo.com/politica/noticia/2020/11/10/bolsonaro-diz-que-brasil-tem-dedeixar-de-ser-pais-de-maricas-e-enfrentar-pandemia-de-peito-aberto.ghtml

Graham-Harrison, Emma, Giuffrida, Angela, Smith, Helena and Ford, Liz (2020) Lockdowns around the world bring rise in domestic violence. The Guardian, 28 March. https://www.theguardian.com/society/2020/mar/28/ lockdowns-world-rise-domestic-violence

Lam, Lydia (2019) NUS to convene review committee after undergrad calls for 'justice' against man who filmed her in shower. Channel News Asia, 20 April. https://www.channelnewsasia.com/news/singapore/ nus-convene-committee-monica-baey-justice-man-film-shower-11462916

Lam, Lydia (2020a) Suspended NUS student gets jail, fine for filming women showering in hall, upskirting internship colleague. Channel News Asia, 20 October. https://www.channelnewsasia.com/news/singapore/ suspended-nus-student-jail-fine-filming-women-showering-upskirt-13320458

Lam, Lydia (2020b) NUS student who climbed into ex-girlfriend's home and strangled her gets short detention and day reporting orders. Channel News Asia, 17 July. https://www.channelnewsasia.com/news/singapore/ nus-student-who-climbed-into-ex-girlfriend-s-home-and-strangled-12941362

Lau, Jean (2020) Sentence for NUS student who tried to strangle exgirlfriend disproportionate to offence: PAP Women's Wing. The Straits Times, 21 July. https://www.straitstimes.com/singapore/courts-crime/ sentence-for-nus-student-who-tried-to-strangle-ex-girlfriend-disproportionate

Lesbian, Gay, Bisexual, Transgender Resource Center (2019) Gender pronouns. University of Wisconsin. https://uwm.edu/lgbtrc/support/gender-pronouns/

McIntosh, Janet (2020) Crybabies and snowflakes. In Janet McIntosh and Norma Mendoza-Denton (eds) Language in the Trump Era: Scandals and Emergencies 74-87. Cambridge: Cambridge University Press.

https://doi.org/10.1017/9781108887410.005

Miyazaki, Hirokazu (2004) The Method of Hope: Anthropology, Philosophy, and Fijan Knowledge. Stanford, CA: Stanford University Press.

Moreira, João Almeida (2020) 'Máscara é coisa de viado,' dizia Bolsonaro a funcionários ['The mask is a thing for fairies', Bolsonaro said to officials]. Diário 
de Notícias, 9 July. https://www.dn.pt/mundo/mascara-e-coisa-de-viado-diziabolsonaro-a-funcionarios-12405019.html

Owoseje, Toyin (2020) Coronavirus is 'the great equalizer', Madonna tells fans from her bathtub. CNN Entertainment, 23 March. https://www.cnn.com/2020/03/23/ entertainment/madonna-coronavirus-video-intl-scli/index.html

Pak, Vincent and Hiramoto, Mie (2020) 'Itching to make an impact': constructing the mobile Singaporean voluntourist in Instagram travel narratives. Social Semiotics. https://doi.org/10.1080/10350330.2020.1766263

Perez-Brumer, Amaya and Silva-Santisteban, Alfonso (2020) COVID-19 policies can perpetuate violence against transgender communities: insights from Peru. AIDS and Behavior 24: 2477-2479. https://doi.org/10.1007/s10461-020-02889-z

Sifat, Ridwan Islam (2020) The effect of COVID-19 on hijra (third gender) people in Bangladesh. The Lancet 7(12): 1015-1016. https://doi.org/10.1016/S2215-0366(20)30464-8

Silva, Daniel N. and Lee, Jerry Wong (2020) 'Marielle, presente': metaleptic temporality and the enregisterment of hope in Rio de Janeiro. Journal of Sociolinguistics. https://doi.org/10.1111/josl.12450

Starr, Rebecca L. and Kapoor, Shrutika (2020) 'Our graduates will have the edge': linguistic entrepreneurship and the discourse of Mandarin enrichment centers in Singapore. Multilingua. https://doi.org/10.1515/multi-2020-0033

Sun, David (2019) 'Potential to excel in life': NUS undergrad who molested woman gets probation for 'minor intrusion' offences. The Straits Times, 26 September. https://www.straitstimes.com/singapore/courts-crime/ university-student-who-molested-woman-gets-probation-for-minor-intrusion

Taylor, Diana (2020) ¡Presente! The Politics of Presence. Durham, NC: Duke University Press.

Teng, Amelia (2019) NUS Peeping Tom given conditional warning due to high likelihood of rehabilitation: Police. The Straits Times, 23 April. https://www. straitstimes.com/singapore/courts-crime/student-in-nus-sexual-misconductcase-given-conditional-warning-due-to-high

UNAIDS (2020) UNAIDS calls for the elimination of the neglected pandemic of violence against women and girls. UNAIDS, 25 November. https://www. unaids.org/en/resources/presscentre/pressreleaseandstatementarchive/2020/ november/20201125_end-violence-against-women

Wareham, Jamie (2020) Murdered, suffered, and burned alive: 350 transgender people killed in 2020. Forbes, 11 November. https:/www.forbes.com/sites/ jamiewareham/2020/11/11/350-transgender-people-have-been-murdered-in2020-transgender-day-of-remembrance-list/?sh=6ed1ce3465a 6

Zimman, Lal (2019) Pronouns and possibilities: transgender language activism and reform. In Netta Avineri, Laura R. Graham, Eric J. Johnson, Robin Conley Riner and Jonathan Rosa (eds) Language and Social Justice in Practice 176-183. New York: Routledge. 